\title{
Total mercury distribution among soil aggregate size fractions in a temperate forest podzol
}

\section{AUTHORS}

\section{Gómez-Armesto}

A. 1,@

angomez@uvigo.es

Bibián-Núñez L. ${ }^{1}$

Campillo-Cora C. ${ }^{1}$

Pontevedra-Pom-

bal X. ${ }^{2}$

Arias-Estévez M. ${ }^{1}$

Nóvoa-Muñoz J.

C. ${ }^{1}$

@ Corresponding Author

${ }^{1}$ Área de Edafoloxía e Química Agrícola.

Facultade de Ciencias. Universidade de Vigo. As Lagoas, s/n. 32004 Ourense, Spain.

${ }^{2}$ Departamento de Edafoloxía e Química Agrícola. Facultade de Bioloxía. Universidade de Santiago de Compostela. Rúa Lope Gómez de Marzoa, s/n. 15782 Santiago de Compostela, A Coruña, Spain.
Distribución de mercurio total en función del tamaño de agregado en un podzol de un bosque templado

Distribuição do mercúrio total em função da dimensão dos agregados num podzol de floresta temperada

Received: 03.04.2017 | Revised: 22.01.2018 | Accepted: 22.01.2018

\section{ABSTRACT}

This study determined the distribution of total $\mathrm{Hg}\left(\mathrm{Hg}_{\mathrm{T}}\right)$ among aggregate size fractions in the A, $\mathrm{E}, \mathrm{Bh}$ and $\mathrm{Bs}$ horizons of a representative temperate forest podzol. The aggregate distribution was dominated by the coarse sand size fraction (average of 55\%) followed by fine sand (29\%), fine silt (10\%), coarse silt (4\%) and clay (2\%). In general, $\mathrm{Hg}_{\mathrm{T}}$ mean values increased as the aggregate size become smaller: clay $\left(170 \mathrm{ng} \mathrm{g}^{-1}\right)>$ fine silt $\left(130 \mathrm{ng} \mathrm{g}^{-1}\right)>$ coarse silt $\left(80 \mathrm{ng} \mathrm{g}^{-1}\right)>$ fine sand $\left(32 \mathrm{ng} \mathrm{g}^{-1}\right)>$ coarse sand $\left(14 \mathrm{ng} \mathrm{g}^{-1}\right)$. Total $\mathrm{Hg}$ enrichment in clay-sized aggregates ranged from 2 to 11 times higher than the values shown by the bulk soil $(<2 \mathrm{~mm})$. The accumulation of $\mathrm{Hg}_{\mathrm{T}}$ in the finer size aggregates was closely related to total organic $\mathrm{C}, \mathrm{Na}$-pyrophosphate extracted $\mathrm{C}$, metal ( $\mathrm{Al}, \mathrm{Fe}$ )humus complexes and $\mathrm{Al}$ and $\mathrm{Fe}$ oxyhydroxides. Indeed, these parameters varied significantly $(p<0.05)$ with the aggregate size and their highest values were found in the finer fractions. This suggested the role of these soil compounds in the increase of the specific surface area per mass unit and negative charges in the smallest aggregates, favouring $\mathrm{Hg}$ retention. Mercury accumulation factor $\left(\mathrm{Hg}_{\mathrm{AF}}\right)$ values reached up to 10.8 in the clay size aggregates, being close to 1 in sand size fractions. Regarding $\mathrm{Hg}$ enrichment factors $\left(\mathrm{Hg}_{\mathrm{EF}}\right)$, they were < 4 ("moderate pollution" category) in most of the horizons and aggregate sizes. Grain size mass loading $\left(\mathrm{GSF}_{\mathrm{Hg}}\right)$ revealed that finer fractions had a higher $\mathrm{Hg}$ loading than their mass fractions, with a notable contribution of fine silt which made up > 50\% of $\mathrm{Hg}_{\mathrm{T}}$ in $\mathrm{Bh}$ and $\mathrm{Bs}$ horizons. The potential ecological risk index $\left(\mathrm{PERI}_{\mathrm{Hg}}\right)$ increased as the aggregate size decreased, with the highest values in the illuvial horizons (45-903) and lowest in the $\mathrm{E}$ horizon (3-363). Heterogeneous distribution of $\mathrm{Hg}$ in the soil aggregate size fractions must be considered for $\mathrm{Hg}$ determination for purposes such as critical loads, background values or environmental risk indices. In addition, $\mathrm{Hg}$ accumulation in finer aggregates could be of concern due to its potential mobility in forest soils, either transferred by leaching to groundwater and freshwaters or mobilized by runoff in surface horizons.

\section{RESUMEN}

En este trabajo se analiza la distribución de $\mathrm{Hg}$ total $\left(\mathrm{Hg}_{T}\right)$ en fracciones de tamaño agregado en los horizontes $\mathrm{A}, \mathrm{E}$, $B$ b y $B$ s de un podzol forestal representativo. La distribución de agregados fue dominada por la fracción de tamaño arena gruesa (promedio del 55\%), seguida arena fina (29\%), limo fino (10\%), limo grueso (4\%) y arcilla (2\%). En 
general, los valores medios de $\mathrm{Hg}_{T}$ incrementaron a medida que el tamaño de los agregados disminuía: arcilla (170 $\left.n g g^{-1}\right)>$ limo fino $\left(130 \mathrm{ng} \mathrm{g}^{-1}\right)>$ limo grueso $\left(80 \mathrm{ng} g^{-1}\right)>$ arena fina $\left(32 \mathrm{ng} \mathrm{g}^{-1}\right)>$ arena gruesa $\left(14 \mathrm{ng} \mathrm{g^{-1 }}\right)$. El enriquecimiento de $\mathrm{Hg}_{T}$ en los agregados de tamaño arcilla varía entre 2 y 11 veces más que los niveles en la fracción tierra fina $(<2 \mathrm{~mm})$. La acumulación de $\mathrm{Hg}_{T}$ en los agregados de menor tamaño estaba estrechamente asociada al $\mathrm{C}$ orgánico total, al $C$ extraído con pirofosfato $\mathrm{Na}$ a a los complejos metal $(\mathrm{Al}, \mathrm{Fe}$ )-humus y a los oxibidróxidos de $\mathrm{Fe}$ y Al. De hecho, estos parámetros variaron significativamente $(\mathrm{p}<0,05)$ con el tamaño de agregado y sus valores más elevados se encontraron en las fracciones más finas. Esto sugiere el papel de estos compuestos del suelo en el incremento de la superficie específica por unidad de masa y de cargas negativas en los agregados más pequeños, favoreciendo la retención de $\mathrm{Hg}$. Los valores del factor de acumulación de $\mathrm{Hg}\left(\mathrm{Hg}_{\mathrm{AF}}\right)$ fueron de hasta 10,8 en los agregados de tamaño arcilla, siendo cercanos a 1 en las fracciones de tamaño arena. Respecto de los factores de enriquecimiento de $\mathrm{Hg}\left(\mathrm{Hg}_{\mathrm{EF}}\right)$, estos fueron < 4 (categoría "contaminación moderada") en la mayoría de los horizontes y tamaños de agregado. El indice de masa por tamaño de agregado $\left(G S F_{H}\right)$ reveló que las fracciones más finas tenían una mayor carga de $\mathrm{Hg}$ que el correspondiente a sus masas, siendo destacable la contribución del limo fino que constituía más del $50 \%$ del $\mathrm{Hg}_{T}$ en los horizontes Bh y Bs. El índice de riesgo ecológico potencial (PERI ${ }_{\mathrm{H}}$ ) aumentó conforme disminuía el tamaño de agregado, con los valores más altos en los horizontes iluviales (45-903) y los más bajos en el horizonte E (3-363). La distribución heterogénea del Hg entre fracciones de tamaño agregado debe ser tenida en cuenta para la determinación de Hg para fines como cargas críticas, valores de fondo geoquimico o indices de riesgos medioambientales. Además, la acumulación de $\mathrm{Hg}$ en los agregados más finos podría ser preocupante debido a su potencial movilidad en suelos forestales, tanto mediante su transferencia por lixiviado a aguas freáticas y superficiales como su movilización por escorrentía en los horizontes superficiales.

\section{RESUMO}

Neste estudo determinou-se a distribuição do $\mathrm{Hg}$ total $\left(\mathrm{Hg}_{\mathrm{T}}\right)$ pelos agregado de diferentes fraçôes nos horizontes $A$, $E, B$ h e Bs de um podzol representativo de floresta temperada. A distribuição dos agregados foi dominada pela fração areia grossa (média de 55\%) seguida de areia fina (29\%), limo fino (10\%), limo grosseiro (4\%) e argila (2\%). Em geral, os valores médios da $\mathrm{Hg}_{T}$ aumentaram à medida que a dimensão do agregado diminuiu: argila (170 $\left.\mathrm{ng} \mathrm{g}^{-1}\right)$ > limo fino $\left(130 \mathrm{ng} \mathrm{g}^{-1}\right)>$ limo grosseiro $\left(80 \mathrm{ng} \mathrm{g}^{-1}\right)>$ areia fina $\left(32 \mathrm{ng} \mathrm{g}^{-1}\right)>$ areia grosseira $\left(14 \mathrm{ng} \mathrm{g}^{-1}\right)$. $\mathrm{O}$ enriquecimento total de $\mathrm{Hg}$ em agregados da dimensão argila variou, sendo de 2 a 11 vezes maior do que os valores na fração terra fina $(<2 \mathrm{~mm})$. A acumulação de $\mathrm{Hg}_{T}$ em agregados de menor dimensão estava intimamente relacionada com o $C$ orgânico total, $C$ extraído com pirofosfato de $\mathrm{Na}$, aos complexos organo-metálicos $(\mathrm{Al}, \mathrm{Fe})$ e aos oxibidróxidos de Fe e Al. De facto, esses parâmetros variaram significativamente ( $\mathrm{p}<0,05)$ com o tamanho do agregado e os valores mais altos ocorreram nas fraçôes mais finas. Isto sugere o papel destes compostos do solo no aumento da superfície especifica e das cargas negativas nos agregados de menor dimensão, favorecendo a retenção do $\mathrm{Hg}$. Os valores do fator de acumulação de $\mathrm{Hg}\left(\mathrm{Hg}_{\mathrm{AF}}\right)$ atingiram o valor de 10,8 nos agregados da dimensão argila, sendo próximos da unidade nas fraçôes areia. Os fatores de enriquecimento do $\mathrm{Hg}\left(\mathrm{Hg}_{E F}\right)$ apresentam valores < 4 (categoria "poluição moderada") na maioria dos horizontes e dimensão de agregados. O indice de massa por dimensão de agregado $\left(G S F_{H g}\right)$ revelou que as fraçôes mais finas apresentam maior carga de $\mathrm{Hg}$ do que as suas fraçôes de massa, sendo notável a contribuição do limo fino ao qual correspondiam valores $>50 \%$ de $\mathrm{Hg}_{\mathrm{T}}$ nos horizontes $B$ b e Bs. O indice de risco ecológico potencial $\left(P E R I_{H}\right)$ aumentou com a diminuição do tamanho do agregado, com os valores mais altos nos horizontes iluviais (45-903) e mais baixos no horizonte E (3-363). A distribuição heterogénea de $\mathrm{Hg}$ nos agregados de várias dimensões deve ser considerada para determinação do $\mathrm{Hg}$ no solo com objetivos tais como cargas críticas, valores de fundo ou indices de risco ambiental. Além disso, a acumulação de $\mathrm{Hg}$ em agregados mais finos pode ser motivo de preocupação devido à sua potencial mobilidade em solos florestais, quer pela sua transferência por lixiviação para as águas subterrâneas e superficiais, quer por mobilização por escoamento superficial desorganizado em horizontes superficiais.

KEYWORDS

Clay, silt, metal

(Al, Fe)-humus complexes, total organic carbon, accumulation factor,

environmental risk assessment.

PALABRAS

CLAVE

Arcilla, limo, complejos metal (A1, $\mathrm{Fe}$ )-humus, carbono orgánico total, factor

de acumulación, evaluación de riesgos ambientales.

\section{PALAVRAS-}

CHAVE

Argila, limo, complexos organometálicos (Al, Fe), carbono orgânico

total, factor de acumulação, avaliação de riscos ambientais. 


\section{Introduction}

Mercury is considered an element of concern due to its accumulation in natural ecosystems that results in harmful effects to wildlife and humans (Driscoll et al. 2013), and is considered to be a global pollutant (Richardson et al. 2013).

Recent estimates consider that approximately $45 \%$ of the atmospheric $\mathrm{Hg}$ is deposited on terrestrial ecosystems (Driscoll et al. 2013), where soils represent its largest reservoir accounting for up to $75 \%$ of the $\mathrm{Hg}$ stored in the biosphere (Mason and Sheu 2002). Mercury is mostly accumulated in the uppermost soils layers due to its high affinity for the thiol groups of soil organic matter (Skyllberg et al. 2006), so $\mathrm{Hg}$ fate in soils is mainly function of the organic carbon dynamics (Smith-Downey et al. 2010). Furthermore, soils are significant $\mathrm{Hg}$ contributors to aquatic environments through its mobilization, which is related to organic matter dynamics (Gunda and Scanlon 2013).

Podzols are a type of soils occurring worldwide, covering about 485 million ha, associated with coarse-textures soils developed from quartzrich and base-poor parent materials (Sauer et al. 2007). Podzolization is considered a crucial process in the mobilization of $\mathrm{Hg}$ from surface horizons, together with dissolved organic matter (Schlüter 1997), toward deeper soil layers where it is accumulated due to its adsorption by $\mathrm{Fe}$ and $\mathrm{Al}$ oxyhydroxides and metal (Al, $\mathrm{Fe}$ )humus complexes (Schuster 1991; Roulet and Lucotte 1995; Roulet et al. 1998; Schlüter 1997; Guedron et al. 2009; Peña-Rodríguez et al. 2014). Thus, the different horizons of podzols would play a decisive role in $\mathrm{Hg}$ mobilization in case of an increase in $\mathrm{Hg}$ availability due to a higher rate of organic matter mineralization as consequence of the global warming (SmithDowney et al. 2010).

Mercury mobility in soils is often estimated by applying chemical reagents that provide information about different chemical forms in which $\mathrm{Hg}$ can be present in the soil solid phase (Biester and Scholz 1997; Fernández-Martínez et al. 2014). However, heavy metal accumulation and distribution in soils and sediments are also strongly affected by the particle size fractions (Cai et al. 2016). Furthermore, Acosta et al. (2009) reported that the accumulation of heavy metals in the smaller particle size fractions could increase their mobility in the environment due to their transport associated to soil colloids.

Studies focused on heavy metal distribution among soil particle size fractions mostly agree on a substantial accumulation of heavy metals in the fractions $<20 \mu \mathrm{m}$ (Acosta et al. 2009; Cai et al. 2016; Yutong et al. 2016; Li et al. 2017). However, investigations related to $\mathrm{Hg}$ distribution among soil aggregate size fractions are limited to soils from cinnabar mines, where a notable increase in $\mathrm{Hg}$ concentrations as the particle size decreases was reported (Fernández-Martínez et al. 2005, 2014). In non-contaminated soils, a larger amount of $\mathrm{Hg}$ in the fraction $<53 \mu \mathrm{m}$ than in the fine earth fraction $(<2 \mathrm{~mm})$ of podzolic soils was found (Do Valle et al. 2005). Similarly, Roulet et al. (1998) and Fiorentino et al. (2011) found that the fraction $<63 \mu \mathrm{m}$ was $\mathrm{Hg}$ enriched compared to bulk soil.

As there are few works focused on the $\mathrm{Hg}$ distribution in aggregate size fractions of soils with background $\mathrm{Hg}$ concentrations $\left(<100 \mathrm{ng} \mathrm{g}^{-1}\right)$, the main aim of this study was to assess the distribution of total $\mathrm{Hg}$ among aggregate size fractions in a representative podzol from a temperate forest area. Relationships between $\mathrm{Hg}$ and soil components involved in $\mathrm{Hg}$ retention will be explored in order to explain the $\mathrm{Hg}$ distribution among aggregate size fractions. Finally, different indices of environmental risks associated to $\mathrm{Hg}$ distribution in different aggregate size fractions will be estimated.

\section{Material and Methods}

\subsection{Study site and soil sampling}

The study site was located on the north-facing slope of Monte Acibro at approximately $450 \mathrm{~m}$ above sea level, in the vicinity of Ferreira do Valadouro (Lugo, NW Spain, coordinates 
$43^{\circ} 34^{\prime} 57.90 " N ; 7^{\circ} 24^{\prime} 59.76$ " W). Soil parent material is a Quaternary quartzitic colluvium and the present forest vegetation consists of a Eucalyptus globulus plantation. Additional information about the study site characteristics is available elsewhere (Ferro-Vázquez et al. 2014).

A representative podzolic soil of the area (Acibro Podzol, abbreviated to AP) was selected in a road bank that was carefully cleaned removing plants and lichens that grow in it. Afterwards, about five kilograms of soil were collected for each of the five horizons identified in the field, namely A, E, $\mathrm{Bh}, \mathrm{Bs} 1$ and Bs2. According to previous studies in a similar soil formation (Ferro-Vázquez et al. 2014), the soil can be classified as Rustic Podzol (IUSS Working Group WRB 2006). Collected soil samples were stored in plastic bags at $4^{\circ} \mathrm{C}$ and transported to the laboratory.

2.2. Soil pretreatment and separation of soil aggregate size fractions

In the laboratory, soil samples were air-dried at $20-25^{\circ} \mathrm{C}$ and then sieved through a mesh size of 2-mm to obtain the fine earth fraction (bulk soil). About $1 \mathrm{~kg}$ of bulk soil was afterwards quartered using a stainless steel riffle-splitter to provide a representative subsample for general physicochemical soil characterization and aggregate size fractionation.

The aggregate size fractionation procedure was slightly modified from that described by Stemmer et al. (1998): the present study combined wet sieving and centrifugation, but did not apply ultrasound for disaggregation. In brief, 150 to $200 \mathrm{~g}$ of bulk soil $(<2 \mathrm{~mm}$ ) of each horizon was mixed with distilled water into $500 \mathrm{~mL}$ plastic bottles at a soil:solution ratio $1: 1$ and then shaken end over end for two hours. Aggregate fractionation was performed therefore without destruction of organic matter and without use of dispersive agents or ultrasonic energy (Semlali et al. 2001), trying to simulate field conditions. After dispersion, soil slurry was wet sieved manually through a 200- $\mu \mathrm{m}$ mesh using distilled water. The material remaining in this sieve was rinsed several times with distilled water to improve the separation between the aggregate fractions corresponding to coarse and fine sand sizes, and afterwards transferred to $300 \mathrm{~mL}$ plastic vessels for drying. Similarly, the material that passed through the 200- $\mu$ m mesh size was subjected again to a wet sieving using a $50-\mu \mathrm{m}$ mesh size, obtaining the aggregate fraction equivalent to fine sand size. Soil material with a mean diameter $<50 \mu \mathrm{m}$ were transferred to 250-mL centrifuge bottles and then centrifuged in a Hettich Rotina 380 centrifuge according to Stokes's Law. Thus, aggregates of coarse and fine silt size were separated from the clay size aggregates by centrifugation at $109 \mathrm{~g}$ for $3 \mathrm{~min}$ and $32 \mathrm{sec}$, whereas fine and coarse silt sized aggregates were separated by centrifugation at $2 \mathrm{~g}$ for $1 \mathrm{~min}$ and $56 \mathrm{sec}$. The centrifugation step (including the material resuspension) was carried out in triplicate to ensure a complete separation among fractions, and the precipitated solids were re-suspended in water before each centrifugation cycle. Afterwards, either supernatants or precipitates were carefully transferred to $300 \mathrm{~mL}$ plastic vessels. The aggregate fractions finally obtained with this procedure, which also include individual particles, corresponded to coarse sand (200$2000 \mu \mathrm{m})$, fine sand $(50-200 \mu \mathrm{m})$, coarse silt $(20-50 \mu \mathrm{m})$, fine silt $(2-20 \mu \mathrm{m})$ and clay $(<2 \mu \mathrm{m})$ size equivalents.

All the aggregate size fractions were air-dried in an oven at $40{ }^{\circ} \mathrm{C}$ and then weighted to assess the degree of recovery and the distribution of the aggregate size fractions. Mass recovery after the fractionation ranged from 92.6 to $99.1 \%$ of the initial soil dry mass in the Bh and Bs2 horizons, respectively. These values are comparable to those reported before for Chinese soils after a similar fractionation procedure (He et al. 2009).

2.3. General physico-chemical characterization of bulk soil $(<2 \mathrm{~mm})$ and aggregate size fractions

General characterization of the bulk soil samples $(<2 \mathrm{~mm})$ of each horizon included the particlesize distribution, determined by the pipette method following wet sieving and sedimentation (Gee and Bauder 1986) and soil pH measured in water $\left(\mathrm{pH}_{\mathrm{w}}\right)$ and saline solution $\left(0.1 \mathrm{M} \mathrm{KCl}, \mathrm{pH}_{\mathrm{k}}\right)$ using a 1:2.5 soil/solution ratio and contact times of 10 minutes and 2 hours, respectively. The total organic carbon and nitrogen contents were determined in finely milled soil samples using a 
Thermo-Finningan 1112 Series NC elemental analyser. The effective cation exchange capacity (eCEC) was estimated as the sum of the base cations ( $\mathrm{K}, \mathrm{Na}, \mathrm{Ca}, \mathrm{Mg}$ ) extracted with $1 \mathrm{M} \mathrm{NH}_{4} \mathrm{Cl}$ (Peech et al. 1947) and the Al extracted with $1 \mathrm{M}$ $\mathrm{KCl}$ (Bertsch and Bloom 1996).

The distribution of $\mathrm{Al}$ and $\mathrm{Fe}$ in the soil solid phase was carried out using $0.1 \mathrm{M} \mathrm{Na}$-pyrophosphate for estimating total metal(AI, Fe)-humus complexes $\left(\mathrm{Al}_{\mathrm{p}}, \mathrm{Fe}_{\mathrm{p}}\right), 0.2 \mathrm{M}$ ammonium oxalate-oxalic acid at $\mathrm{pH} 3$ to assess the contents of non-crystalline $\mathrm{Al}$ and $\mathrm{Fe}$ compounds $\left(\mathrm{Al}_{\mathrm{o}}\right.$ and $\left.\mathrm{Fe}_{\mathrm{o}}\right), 0.5 \mathrm{M} \mathrm{NaOH}$ and $\mathrm{Na}$-dithionite-citrate as an approximation to total "reactive" forms of $\mathrm{Al}\left(\mathrm{Al}_{\mathrm{n}}\right)$ and $\mathrm{Fe}\left(\mathrm{Fe}_{\mathrm{d}}\right)$. Further details of these procedures are reported elsewhere (García-Rodeja et al. 2004). In the Na-pyrophosphate extracts, the amount of $\mathrm{C}$ solubilised $\left(C_{p}\right)$ was also determined by wet oxidation using $1.8 \mathrm{~N}$ potassium dichromate and subsequent titration with ferrous ammonium sulphate.

In the soil aggregate size fractions, total $\mathrm{C}$ and $\mathrm{N}$ contents and $\mathrm{Al}$ and $\mathrm{Fe}$ distribution were analysed following the procedures described previously.

\subsection{Total mercury analysis}

Total $\mathrm{Hg}\left(\mathrm{Hg}_{\mathrm{T}}\right)$ was determined in bulk soil samples as well as in aggregate size fractions. Except for the aggregate fraction of clay size, samples were finely milled in an agate mortar before $\mathrm{Hg}$ determination. Mercury analyses were conducted by atomic absorption spectroscopy after thermal combustion using a Nippon Model MA-2000 total $\mathrm{Hg}$ analyzer. Details about standards, detection limit, working range and sample mass needed for analysis are described elsewhere (Peña-Rodríguez et al. 2014). All samples were analyzed in duplicate.

For quality assurance and control (QA/QC) purposes, samples analyses were repeated when the coefficient of variation exceeded $10 \%$. Moreover, standard reference materials BCR 142-R (soil, $67 \pm 11 \mathrm{ng} \mathrm{g}^{-1} \mathrm{Hg}$ ), CC-141 (soil, $83 \pm 17 \mathrm{ng} \mathrm{g}^{-1} \mathrm{Hg}$ ), NCS DC73323 (soil, $290 \pm 30 \mathrm{ng} \mathrm{g}^{-1} \mathrm{Hg}$ ), CRM-024 (soil, $710 \pm$ $34 \mathrm{ng} \mathrm{g}^{-1} \mathrm{Hg}$ ) and BCR-143R (soil, $1100 \pm$ $70 \mathrm{ng} \mathrm{g}^{-1} \mathrm{Hg}$ ) were measured at each analytical run obtaining recoveries ranging 97 to $102 \%$. When the percentage of recovery of the certified standards was above $10 \%$, the $\mathrm{Hg}$-analyzer was recalibrated and the last batch of samples measured was re-analyzed. All the mercury values are expressed as the oven-dry weight $\left(105^{\circ} \mathrm{C}\right)$.

\subsection{Assessment of total $\mathrm{Hg}$ distribution in aggregate size fractions}

Several indices will be estimated, which could provide useful information for environmental risk, such as the degree of accumulation and distribution of $\mathrm{Hg}$ in aggregate size fractions. Accumulation factor is often used to assess the aggregate size fraction that is more likely to be enriched in heavy metals (Acosta et al. 2009; Li et al. 2017). The mercury accumulation factor $\left(\mathrm{Hg}_{\mathrm{AF}}\right)$ in each aggregate size fraction regard to bulk soil is calculated as:

$$
H g_{A F}=\frac{H g_{\text {fraction }}}{H g_{\text {bulk }}}
$$

where $\mathrm{Hg}_{\text {fraction }}$ and $\mathrm{Hg}_{\text {bulk }}$ are the concentrations of total $\mathrm{Hg}\left(\mathrm{ng} \mathrm{g}^{-1}\right)$ in a given aggregate size fraction and the bulk soil $(<2 \mathrm{~mm})$, respectively.

Mercury enrichment factor $\left(\mathrm{Hg}_{\mathrm{EF}}\right)$ in bulk soil and in aggregate size fractions was estimated according to a double normalization including a conservative element $(\mathrm{Al})$. It is expected that as greater is the $\mathrm{Hg}_{\mathrm{EF}}$ than unity, greater will be the anthropogenic influence in the accumulation of $\mathrm{Hg}$ departing from lithological background values. Thus, $\mathrm{Hg}_{\mathrm{EF}}$ was calculated as:

$$
H g_{E F}=\left[\frac{H g_{i} / A l_{i}}{H g_{C} / A l_{C}}\right]
$$

where $\mathrm{Hg}_{\mathrm{i}}$ is the concentration of total $\mathrm{Hg}\left(\mathrm{ng} \mathrm{g}^{-1}\right)$ in bulk soil or aggregate size fractions, and $\mathrm{Hg}_{\mathrm{C}}$ is the concentration of total $\mathrm{Hg}\left(\mathrm{ng} \mathrm{g}^{-1}\right)$ in the deeper horizon (BwC) of podzols collected from the same study site (Gómez-Armesto et al. 2015). $\mathrm{Al}_{\mathrm{i}}$ and $\mathrm{Al}_{\mathrm{C}}$ are the concentrations of $\mathrm{NaOH}$-extracted $\mathrm{Al}\left(\mathrm{g} \mathrm{kg}^{-1}\right)$ in bulk soil or aggregate size fractions and in the deeper horizon (BwC), respectively. 
Grain size mass loading (GSF) is an index that combines heavy metal concentrations in aggregate size fractions with the mass percentage of a given aggregate size fraction (Sutherland 2003). Thus, the $\mathrm{Hg}$ contribution of a given size fraction to total concentration of $\mathrm{Hg}$ in the bulk sample will depend on its concentration and mass loading. The GSF for $\mathrm{Hg}$ was calculated as:

$$
G S F_{H g}=\left[\frac{H g_{i} \times G S_{i}}{\sum_{1}^{5} H g_{i} \times G S_{i}}\right] \times 100
$$

where $\mathrm{Hg}_{\mathrm{i}}$ and $\mathrm{GS}$, are mercury concentration for a given aggregate size fraction $\left(\mathrm{ng} \mathrm{g}^{-1}\right)$ and the percentage by mass of the size fraction $i$ in the total sample, respectively.

The potential ecological risk index (PERI ${ }_{\mathrm{Hg}}$ ), originally proposed by Hakanson (1980), was applied to assess the ecological risk degree of a single heavy metal in various soil aggregate size fractions ( $\mathrm{Li}$ et al. 2017). This index was calculated as:

$$
P E R I_{H g}=\frac{c_{a s f}}{C_{b k}} \times T_{r}
$$

where $\mathrm{C}_{\mathrm{asf}}$ and $\mathrm{C}_{\mathrm{bk}}$ were the concentration of total $\mathrm{Hg}\left(\mathrm{ng} \mathrm{g}^{-1}\right)$ in a single aggregate size fraction and in the soil parent material (quartzite), respectively. Average of $\mathrm{Hg}$ concentration in quartzite samples of the study area is $14 \mathrm{ng} \mathrm{g}^{-1}$. $T_{r}$ is the toxic response factor whose value for $\mathrm{Hg}$ was established in 40 (Hakanson 1980). According to Hakanson (1980), the values of PERI for an individual heavy metal are classified in five levels: slight risk $(<40)$, medium risk $(40-$ $79)$, high risk (80-159), very high risk (160-319) and extremely high risk $(\geq 320)$.

\subsection{Statistical analysis}

Basic and descriptive statistics were used to obtain mean and standard deviations of studied parameters. Simple correlation analysis were applied to assess the relationships between total $\mathrm{Hg}$ and parameters related to soil organic matter and $\mathrm{Al}$ and $\mathrm{Fe}$ compounds estimated in aggregate size fractions. One-way analysis of variance (ANOVA) was performed to test if the aggregate size was a factor of variation for total $\mathrm{Hg}$ and other chemical parameters among separated aggregate fractions. For all these analyses, the results were considered significant when $P<0.05$. All statistical analyses were carried out using SPSS version 20.0 for Windows.

\section{Results and Discussion}

\subsection{General characteristics of soils}

General physico-chemical characteristics of the Acibro Podzol are shown in Table 1. Particlesize distribution in the studied soil is dominated by the sand fraction (> 70\%), with an increase of the clay fraction in deeper soil horizons. Soil texture ranges from sandy in $A$ and $E$ horizons, to loamy sand or sandy clay loam in the illuvial horizons. The entire soil profile has a strong acid reaction $\left(\mathrm{pH}_{\mathrm{w}}<4.5\right)$ and total organic $\mathrm{C}$ peaks at the $\mathrm{A}$ and $\mathrm{Bh}$ horizons with 44 and $56 \mathrm{~g} \mathrm{~kg}^{-1}$, respectively. The effective cation exchange capacity (eCEC) is very low in all horizons $\left(<7.5 \mathrm{cmol}_{\mathrm{c}} \mathrm{kg}^{-1}\right)$ and dominated by exchangeable Al, while the sum of base cations scarcely reaches $0.6 \mathrm{cmol}_{\mathrm{c}} \mathrm{kg}^{-1}$. Soil "reactive" $\mathrm{Al}$ and $\mathrm{Fe}$ compounds, which includes metal (Al, Fe)-humus complexes and non-crystalline and crystalline $\mathrm{Al}$ and $\mathrm{Fe}$ oxyhydroxides, are clearly accumulated in the illuvial horizons (Bh and $\mathrm{Bs}$ ) whereas their presence in the $\mathrm{E}$ horizon is almost negligible (often $<0.1 \mathrm{~g} \mathrm{~kg}^{-1}$ ). Metal(Al, $\mathrm{Fe})$-humus complexes $\left(\mathrm{Al}_{\mathrm{p}}, \mathrm{Fe}_{\mathrm{p}}\right)$ dominate the distribution of both metals in the entire soil (Table 1), as can be deduced from the $\mathrm{Al}_{\mathrm{p}} / \mathrm{Al}$ 。 and $\mathrm{Fe}_{\mathrm{p}} / \mathrm{Fe}_{\mathrm{o}}$ ratios close to 1 .

The studied soil shows the typical features of a podzol, where the podzolization process was facilitated by the coarse soil texture in the A horizon and the lack of weatherable minerals in the soil parent material (Aguilar et al. 1980). The distribution of total organic $C$ in the Acibro Podzol is in agreement with the classical fulvate theory, which maintains the role of organic acids 
in the mobilization, transport and accumulation of $\mathrm{Al}$ and $\mathrm{Fe}$ compounds in podzols (Buurman and Jongmans 2005). The accumulation of secondary $\mathrm{Al}$ and $\mathrm{Fe}$ compounds in $\mathrm{Bh}$ and Bs horizons is in agreement with that observed in previous studies on podzols (Sauer et al. 2007; Ferro-Vázquez et al. 2014).

Table 1. Physico-chemical characteristics of the Acibro Podzol

\begin{tabular}{|c|c|c|c|c|c|c|c|c|c|c|c|c|c|c|c|c|c|c|}
\hline Hor & Depth & Sand & Silt & Clay & $\mathrm{pH}_{\mathrm{w}}{ }^{\mathrm{a}}$ & $\mathrm{pH}_{\mathrm{k}}{ }^{\mathrm{a}}$ & C & $\mathbf{N}$ & $\mathrm{SB}^{\mathrm{b}}$ & Al & eCEC $^{b}$ & SAI ${ }^{b}$ & $\mathrm{Al}_{\mathrm{p}}^{\mathrm{c}}$ & $\mathrm{Al}_{0}^{\mathrm{c}}$ & $\mathrm{Al}_{\mathrm{n}}^{\mathrm{c}}$ & $\mathrm{Fe}_{\mathrm{p}}{ }^{\mathrm{c}}$ & $\mathrm{Fe}_{0}{ }^{\mathrm{c}}$ & $\mathrm{Fe}_{\mathrm{d}}{ }^{\mathrm{c}}$ \\
\hline & $\mathrm{cm}$ & \multicolumn{5}{|c|}{------- \% --------- } & \multicolumn{2}{|c|}{$-g k g^{-1}-$} & \multicolumn{3}{|c|}{ - $\mathrm{cmol}_{\mathrm{c}} \mathrm{kg}^{-1}$} & $\%$ & \multicolumn{6}{|c|}{ - } \\
\hline$A$ & $0-15$ & 85 & 7 & 8 & 3.9 & 3.1 & 44 & 2.4 & 0.4 & 3.1 & 3.5 & 88 & 1.1 & 1.0 & 1.3 & 0.3 & 1.0 & 1.4 \\
\hline$E$ & $15-42$ & 88 & 6 & 6 & 4.5 & 3.7 & 4 & 0.3 & 0.3 & 0.5 & 0.8 & 60 & 0.1 & 0.1 & 0.2 & 0.1 & 0.1 & 0.7 \\
\hline $\mathrm{Bh}$ & $42-50$ & 70 & 15 & 15 & 4.2 & 3.6 & 56 & 3.2 & 0.6 & 6.9 & 7.5 & 93 & 5.7 & 5.9 & 6.7 & 7.6 & 8.4 & 14.3 \\
\hline Bs1 & $50-60$ & 72 & 8 & 20 & 4.5 & 4.2 & 18 & 0.8 & 0.5 & 1.6 & 2.1 & 77 & 5.6 & 6.0 & 7.1 & 11.6 & 14.3 & 19.0 \\
\hline Bs2 & $60-80$ & 76 & 11 & 13 & 4.5 & 4.4 & 8 & 0.4 & 0.3 & 0.8 & 1.1 & 73 & 3.5 & 4.0 & 6.2 & 5.3 & 5.6 & 11.0 \\
\hline
\end{tabular}

${ }^{\mathrm{a}} \mathrm{pH}_{\mathrm{w}}$ and $\mathrm{pH}_{\mathrm{k}}$ are $\mathrm{pH}$ values measured in distilled water and $0.1 \mathrm{M} \mathrm{KCl}$, respectively.

bSB, eCEC and SAl are sum of base cations ( $\mathrm{Na}, \mathrm{K}, \mathrm{Ca}, \mathrm{Mg})$, effective cation exchange capacity and $\mathrm{Al}$ saturation in cation exchange complex, respectively.

${ }^{c} \mathrm{Al}_{\mathrm{p}}\left(\mathrm{Fe}_{\mathrm{p}}\right), \mathrm{Al}_{\mathrm{o}}\left(\mathrm{Fe}_{\mathrm{o}}\right), \mathrm{Al}_{\mathrm{n}}$ and $\mathrm{Fe}_{\mathrm{d}}$ : $\mathrm{Al}(\mathrm{Fe})$ extracted with Na-pyrophosphate (p), ammonium oxalate-oxalic acid (o), Al extracted with $\mathrm{Na}$ hydroxide $(\mathrm{n})$ and Fe extracted with $\mathrm{Na}$-dithionite-citrate $(\mathrm{d})$, respectively.

3.2. Total mercury content in aggregate size fractions

\subsubsection{Aggregate size distribution in the Acibro Podzol}

The mass percentage for each aggregate size fraction is shown in Figure 1. In all horizons, coarse sand-sized aggregates become the dominant fraction ranging from 44 to $69 \%$ of the total soil weight (average 55\%), followed by the fine-sand aggregates with a mean value of $29 \%$. Fine silt had a mean occurrence of $10 \%$ (range $3-17 \%$ ), whereas aggregate fractions corresponding to coarse silt and clay sizes had the smallest contribution with mean values of $4 \%$ and $2 \%$, respectively. The absence of additional measures for soil dispersion, such as ultrasonic treatments or chemical dispersants, and the particle size distribution of the soil (Table 1) are consistent with the low mass percentages obtained for the finer aggregate size fractions. Furthermore, the prevalence of sand-sized aggregates is frequently reported during the assessment of heavy metals, $\mathrm{C}$ and $\mathrm{N}$ distribution in soils depending on particle size (Ljung et al. 2006; Acosta et al. 2009; He et al. 2009; Luo et al. 2011; Li et al. 2017).

\subsubsection{Total mercury distribution in bulk and aggregate size particles}

The total $\mathrm{Hg}$ concentration $\left(\mathrm{Hg}_{\mathrm{T}}\right)$ in bulk soil samples (<2 mm) ranged from 12 to $61 \mathrm{ng} \mathrm{g}^{-1}$, with the highest values in the Bs1 layer and the lowest in the eluvial horizon (Table 2). These low levels of $\mathrm{Hg}_{\mathrm{T}}$ suggest that the studied soil was not significantly influenced by anthropogenic $\mathrm{Hg}$, as values below $100 \mathrm{ng} \mathrm{g}^{-1}$ are considered to be a natural background content in soils (Xin and Gustin 2007).

Depth pattern of $\mathrm{Hg}_{\mathrm{T}}$ in the Acibro Podzol is consistent with the role of the podzolization as the main mechanism involved in $\mathrm{Hg}$ mobilization from $E$ horizons, together with dissolved organic matter, towards deeper soil layers (Schuster 1991). A similar pattern of $\mathrm{Hg}_{\mathrm{T}}$ with soil depth has been reported for podzolic soils worldwide (Roulet et al. 1998; Do Valle et al. 2005; PeñaRodríguez et al. 2014).

The concentration of $\mathrm{Hg}_{\mathrm{T}}$ was not homogenous among the separated aggregate size fractions of the soil horizons, increasing as the size of the aggregates becomes smaller (Table 2). A one-way analysis of variance (ANOVA) showed that aggregate size was a statistically significant 


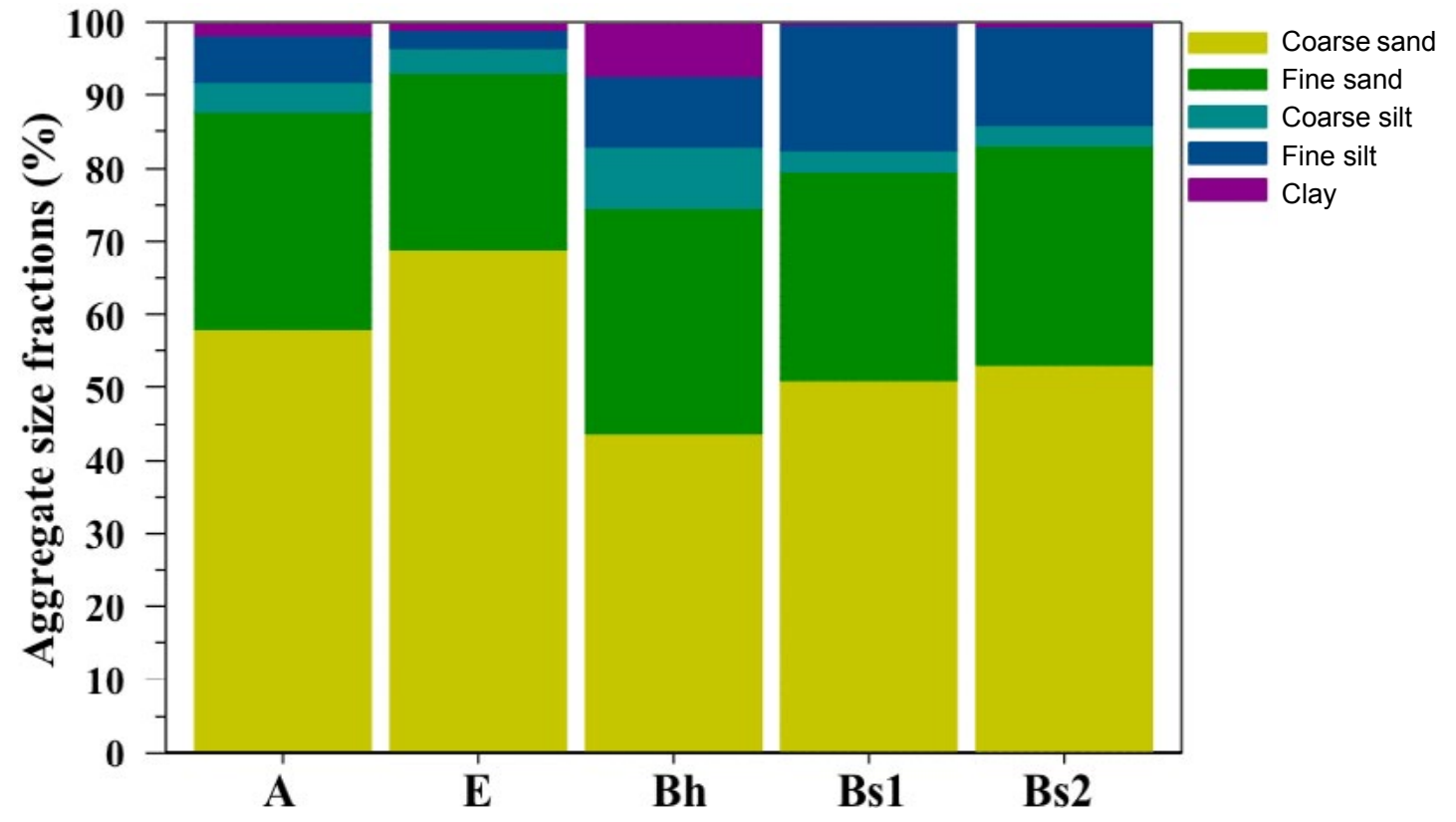

Figure 1. Distribution of aggregate size fractions in the horizons of the Acibro Podzol.

factor of variation for $\mathrm{Hg}_{\mathrm{T}}(F=8.114 ; p=0.000)$. The highest $\mathrm{Hg}_{\mathrm{T}}$ mean value was shown for the clay-size aggregate fraction (179 $\left.\mathrm{ng} \mathrm{g}^{-1}\right)$, followed by fine silt (130 $\left.\mathrm{ng} \mathrm{g}^{-1}\right)$, coarse silt (80 $\left.\mathrm{ng} \mathrm{g}^{-1}\right)$, fine sand (32 $\left.\mathrm{ng} \mathrm{g}^{-1}\right)$ and coarse sand $\left(14 \mathrm{ng} \mathrm{g}^{-1}\right)$. The accumulation of $\mathrm{Hg}_{\mathrm{T}}$ in the claysized material compared to the bulk soil $(<2 \mathrm{~mm})$ ranged from 2 (in the $\mathrm{Bh}$ horizon) to 11 times (in the $\mathrm{E}$ horizon). Similar $\mathrm{Hg}_{\mathrm{T}}$ enrichments (range 3-19) were found by Inácio et al. (1998) in podzol horizons when compared the fraction $<63 \mu \mathrm{m}$ and the fine earth fraction.

The accumulation of $\mathrm{Hg}_{\mathrm{T}}$ in the finest aggregate size fractions (fine silt and clay) agrees with that reported in previous studies in soils with background $\mathrm{Hg}$ levels. Thus, Roulet et al. (1998) observed in ultisols, oxisols and spodols a $\mathrm{Hg}_{\mathrm{T}}$ enrichment in the $<63 \mu \mathrm{m}$ fraction (which included silt and clay size particles) of 2-7 times compared to coarser fractions. Similarly, do Valle et al. (2005) also found 2 to 9 times more $\mathrm{Hg}$ in the $<53 \mu \mathrm{m}$ fraction than in the fine earth fraction in a variety of soils including podzols, whereas Fiorentino et al. (2011) also detected a significant enrichment of $\mathrm{Hg}$ in the $<63 \mu \mathrm{m}$ fraction of a ferralsol compared to the bulk soil. More recently, Qin et al. (2014) also demonstrated a significant increase in $\mathrm{Hg}$ concentration as the size of particle fractions diminished in the uppermost soil layers (0-15 cm). Total $\mathrm{Hg}$ accumulation in the finer aggregate size fractions was also reported in contaminated soils, resulting in a $\mathrm{Hg}$ enrichment in the fractions < $147 \mu \mathrm{m}$ (Fernández-Martínez et al. 2005, 2014).

The preferential accumulation of $\mathrm{Hg}$ in the smaller aggregates of the horizons of the Acibro Podzol can be justified by its larger specific surface area per mass unit, and the presence of a large pool of negative charges derived from the secondary clay minerals and organic matter accumulated in the finer aggregates. This is supported by the increase of total organic $\mathrm{C}$, Na-pyrophosphate extractable $\mathrm{C}$, metal(Al, Fe)-humus complexes and $\mathrm{Al}$ and $\mathrm{Fe}$ oxyhydroxides observed as aggregate size fractions become smaller (Table 2), particularly for the clay-sized and silt-sized aggregates of the $\mathrm{Bh}$ and Bs horizons. Indeed, total organic $C$ varied significantly with the aggregate size $(F=4.265, p=0.012)$, being in agreement with the sequence clay>silt>sand reported previously ( $\mathrm{He}$ et al. 2009). Taking into account the strong association between soil organic $\mathrm{C}$ and soil $\mathrm{Hg}$ accumulation (Skyllberg et al. 2006; Smith-Downey et al. 2010), it is expected that the organic $C$ enrichment observed 
Table 2. General chemical characteristics and total $\mathrm{Hg}$ content $\left(\mathrm{Hg}_{\mathrm{T}}\right)$ in the bulk soil (BS) and in the aggregate size fractions of the Acibro Podzol. CSa (coarse sand), FSa (fine sand), CSi (coarse silt), FSi (fine silt) and Cla (clay)

\begin{tabular}{|c|c|c|c|c|c|c|c|c|c|c|c|c|}
\hline \multirow[t]{2}{*}{ Hor } & & C & $\mathbf{N}$ & $\mathrm{C} / \mathrm{N}$ & $\mathrm{C}_{\mathrm{p}}{ }^{\mathrm{a}}$ & $A I_{p}^{b}$ & $\mathrm{Al}_{0}^{\mathrm{b}}$ & $\mathrm{Al}_{\mathrm{n}}{ }^{\mathrm{b}}$ & $\mathrm{Fe}_{\mathrm{p}}{ }^{\mathrm{b}}$ & $\mathrm{Fe}_{0}{ }^{b}$ & $\mathrm{Fe}_{\mathrm{d}}^{\mathrm{b}}$ & $\mathrm{Hg}_{\mathrm{T}}$ \\
\hline & $\mathrm{cm}$ & \multicolumn{3}{|c|}{$-g k g^{-1}-$} & \multicolumn{7}{|c|}{--- $\mathrm{g} \mathrm{kg}^{-1}$} & $n g g^{-1}$ \\
\hline \multirow[t]{6}{*}{ A } & BS & 44 & 2.4 & 18 & 18 & 1.1 & 1.0 & 1.3 & 0.3 & 1.0 & 1 & 25 \\
\hline & $\mathrm{CSa}$ & 15 & $<1.0$ & $>15$ & 7 & $<0.1$ & $<0.1$ & $<0.1$ & 0.1 & 0.1 & 1 & 9 \\
\hline & $\mathrm{FSa}$ & 64 & 3.2 & 20 & 19 & 1.4 & 1.0 & 1.1 & 0.4 & 0.7 & 1 & 24 \\
\hline & $\mathrm{CSi}$ & 94 & 4.5 & 21 & 24 & 3.0 & 3.4 & 3.0 & 0.8 & 2.5 & 5 & 58 \\
\hline & $\mathrm{FSi}$ & 212 & 9.9 & 21 & 36 & 6.4 & 6.3 & 6.8 & 5.2 & 5.3 & 76 & 97 \\
\hline & $\mathrm{Cla}$ & 244 & 15.4 & 16 & 58 & 7.8 & 8.1 & 8.4 & 7.0 & 6.3 & 108 & 163 \\
\hline \multirow[t]{6}{*}{$E$} & BS & 4.1 & 0.3 & 14 & n.d. & 0.1 & 0.1 & 0.2 & 0.1 & 0.1 & 1 & 12 \\
\hline & $\mathrm{CSa}$ & $<0.1$ & $<1.0$ & n.d. & 7 & $<0.1$ & $<0.1$ & $<0.1$ & $<0.1$ & $<0.1$ & 1 & 1 \\
\hline & $\mathrm{FSa}$ & 3 & $<1.0$ & $>3$ & 2 & $<0.1$ & $<0.1$ & $<0.1$ & 0.1 & $<0.1$ & 1 & 4 \\
\hline & $\mathrm{CSi}$ & 8 & $<1.0$ & $>8$ & 5 & $<0.1$ & 0.5 & 0.6 & 0.3 & 1.5 & 3 & 27 \\
\hline & $\mathrm{FSi}$ & 49 & 2.9 & 17 & 35 & 2.0 & 1.8 & 2.2 & 2.7 & 2.4 & 65 & 39 \\
\hline & $\mathrm{Cla}$ & 126 & 8.6 & 15 & 32 & 4.9 & 4.8 & 5.8 & 7.0 & 6.0 & 133 & 127 \\
\hline \multirow[t]{6}{*}{$\mathrm{Bh}$} & BS & 56 & 3.2 & 18 & 33 & 5.7 & 5.9 & 6.7 & 7.6 & 8.4 & 14 & 45 \\
\hline & CSa & 26 & 1.1 & 23 & 12 & 2.7 & 1.3 & 1.6 & 2.7 & 3.2 & 45 & 20 \\
\hline & $\mathrm{FSa}$ & 57 & 2.8 & 20 & 37 & 6.4 & 5.4 & 5.8 & 5.4 & 7.4 & 123 & 49 \\
\hline & CSi & 116 & 5.7 & 20 & 42 & 13.5 & 15.9 & 14.4 & 18.9 & 17.8 & 260 & 107 \\
\hline & FSi & 134 & 7.2 & 19 & 53 & 15.4 & 15.9 & 15.6 & 18.4 & 17.4 & 278 & 110 \\
\hline & Cla & 120 & 7.2 & 17 & 40 & 15.6 & 13.6 & 15.2 & 19.8 & 13.8 & 317 & 93 \\
\hline \multirow[t]{6}{*}{ Bs1 } & BS & 18 & 0.8 & 23 & 12 & 5.6 & 6.0 & 7.1 & 11.6 & 14.3 & 19 & 61 \\
\hline & $\mathrm{CSa}$ & 6 & $<1.0$ & $>6$ & 5 & 1.8 & 1.0 & 1.0 & 4.1 & 2.6 & 33 & 24 \\
\hline & $\mathrm{FSa}$ & 18 & $<1.0$ & $>18$ & 11 & 5.5 & 3.1 & 3.6 & 10.2 & 7.1 & 122 & 58 \\
\hline & $\mathrm{CSi}$ & 35 & 1.4 & 25 & 12 & 10.3 & 10.9 & 14.4 & 29.3 & 21.9 & 391 & 126 \\
\hline & $\mathrm{FSi}$ & 58 & 2.4 & 24 & 22 & 17.6 & 18.9 & 23.8 & 42.4 & 37.0 & 671 & 196 \\
\hline & $\mathrm{Cla}$ & 64 & 4.6 & 14 & n.d. & 21.1 & 21.6 & 21.8 & 46.8 & 36.1 & n.d. & 197 \\
\hline \multirow[t]{6}{*}{ Bs2 } & BS & 8 & 0.4 & 20 & 7 & 3.5 & 4.0 & 6.2 & 5.3 & 5.6 & 11 & 51 \\
\hline & $\mathrm{CSa}$ & 3 & $<1.0$ & $>3$ & 7 & 1.0 & 0.8 & 1.4 & 1.8 & 1.2 & 2 & 16 \\
\hline & $\mathrm{FSa}$ & 6 & $<1.0$ & $>6$ & 6 & 2.7 & 1.7 & 2.5 & 2.8 & 2.5 & 57 & 24 \\
\hline & $\mathrm{CSi}$ & 15 & 0.4 & 38 & 10 & 6.7 & 7.9 & 11.6 & 11.2 & 10.4 & 213 & 84 \\
\hline & FSi & 37 & 1.6 & 23 & 20 & 14.1 & 20.5 & 27.0 & 25.2 & 23.0 & 461 & 207 \\
\hline & $\mathrm{Cla}$ & 117 & 3.5 & 34 & n.d. & 22.1 & 28.2 & 41.6 & 26.8 & 27.1 & n.d. & 316 \\
\hline
\end{tabular}

aCarbon solubilised in the Na-pyrophosphate extract.

${ }^{b} \mathrm{Al}_{\mathrm{p}}\left(\mathrm{Fe}_{\mathrm{p}}\right), \mathrm{Al}_{\mathrm{o}}\left(\mathrm{Fe}_{\mathrm{o}}\right)$, Aln and $\mathrm{Fe}_{\mathrm{d}}$ : $\mathrm{Al}(\mathrm{Fe})$ extracted with Na-pyrophosphate (p), ammonium oxalate-oxalic acid (o), Al extracted with $\mathrm{Na}$ hydroxide (n) and Fe extracted with $\mathrm{Na}$-dithionite-citrate (d), respectively.

in the finer fractions is partially responsible for the increase of $\mathrm{Hg}$ concentrations in them. In fact, total organic $\mathrm{C}$ was correlated to $\mathrm{Hg}_{\mathrm{T}}$ considering all the aggregates from different horizons as a whole $(r=0.462, p=0.023)$.
However, a better correlation was obtained between $\mathrm{Hg}_{\mathrm{T}}$ and Na-pyrophosphate extracted $\mathrm{C}$ $(r=0.538, p=0.008)$ suggesting that humified organic matter would participate more closely than total organic $\mathrm{C}$ in the $\mathrm{Hg}$ enrichment showed 
by finer aggregates. Quality of organic matter rather than quantity has already been considered crucial for Hg binding (Jing et al. 2007).

In the present study, the contents of Alhumus complexes $\left(\mathrm{Al}_{\mathrm{p}}\right.$ ) and non-crystalline Al compounds $\left(\mathrm{Al}_{\mathrm{o}}\right)$ varied significantly with the aggregate size $(F=3.361, p=0.035$ and $F=3.266, p=0.037$, respectively). Moreover, Alhumus complexes and total "reactive" $\mathrm{Fe}\left(\mathrm{Fe}_{\mathrm{d}}\right)$ were significantly correlated to $\mathrm{Hg}_{\mathrm{T}}(r=0.857$, $p=0.000 ; r=0.840, p=0.000$, respectively, (Figure 2). This suggested that metal(Al, $\mathrm{Fe}$ )humus complexes and $\mathrm{Al}$ and $\mathrm{Fe}$ oxyhydroxides were also involved in the accumulation of $\mathrm{Hg}$ shown by the smaller size aggregates in the different soil horizons. This is consistent with the results obtained by Guedron et al. (2009), who attributed the accumulation of $\mathrm{Hg}$ in the clay-size fraction $(<2 \mu \mathrm{m})$ of French Guiana soils to inorganic amorphous and crystalline compounds of $\mathrm{Fe}$ and $\mathrm{Al}$ as well as fine organic matter. In addition, the role of metal( $\mathrm{Al}, \mathrm{Fe})$ humus complexes and $\mathrm{Al}$ and Fe oxyhydroxides in $\mathrm{Hg}$ retention in podzols and podzolic soils is often recognized in the literature (Roulet and Lucotte 1995; Richardson et al. 2013; PeñaRodríguez et al. 2014).
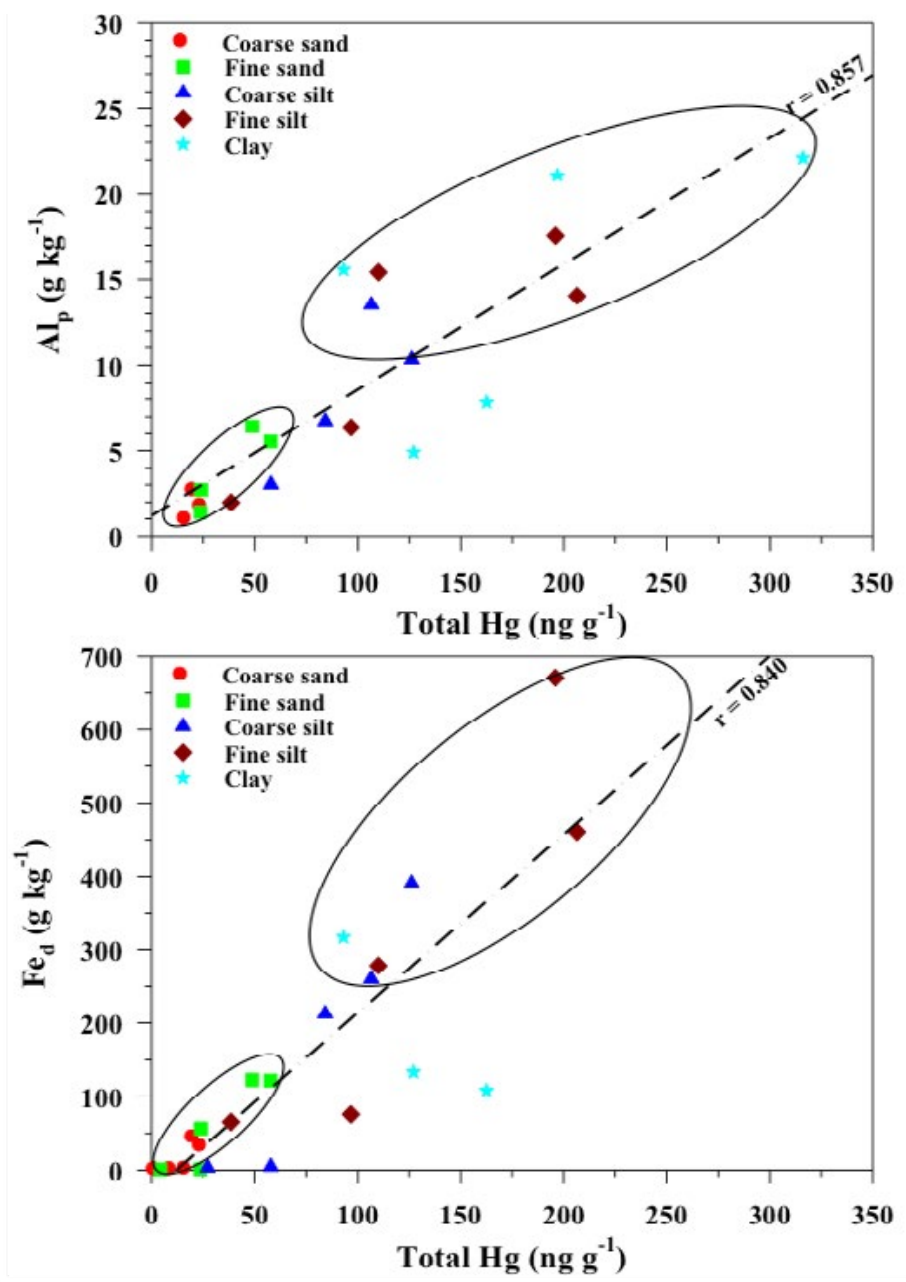

Figure 2. Relationships between total $\mathrm{Hg}$ and total $\mathrm{Al}$-humus complexes $\left(\mathrm{Al}_{\mathrm{p}}\right)$ and total "reactive" $\mathrm{Fe}\left(\mathrm{Fe}_{\mathrm{d}}\right)$ in the aggregate size fractions of the Acibro Podzol. The ellipses discriminate between coarser and finer aggregate size fractions. 
3.3. Indices of $\mathrm{Hg}$ distribution in aggregate size fractions

The values of $\mathrm{Hg}$ accumulation factor $\left(\mathrm{Hg}_{\mathrm{AE}}\right)$ calculated for the Acibro Podzol indicates a notable metal enrichment in the finer fractions, particularly in the fine silt and clay aggregates (Figure 3). This is in agreement with the suggestion of Ljung et al. (2006) who considered that in sandy soils with a small amount of finer particles, as in the Acibro Podzol, the limited availability of binding sites for heavy metals leads to its accumulation in finer particles.

The increasing trend of $\mathrm{Hg}_{\mathrm{AF}}$ values with decreasing aggregate size was observed for all the horizons, although they were somewhat higher for clay aggregates of $A$ and $E$ horizons, with values of 6.6 and 10.8 , respectively. These values are similar to the average of 7.9 obtained for $\mathrm{Hg}_{\mathrm{AF}}$ in the clay fraction of soils from a gold mining area (Li et al. 2014), but they were higher than those obtained by Qin et al. (2014) in this fraction for soils in an iron ore area. On the contrary, aggregate size fractions corresponding to coarse and fine sand sizes showed $\mathrm{Hg}_{\mathrm{AF}}$ values close to 1 , suggesting that these fractions were not significantly involved in $\mathrm{Hg}$ accumulation in the studied soil. This is likely due to the composition of sand-size aggregate fractions in the Acibro Podzol which is expected to be dominated by quartz $\left(\mathrm{SiO}_{2}\right)$. Larger values of $A F$ in the fine fractions and lower values in the coarse ones are usually reported in studies focused on heavy metal distribution among aggregate size fractions in different soils (Acosta et al. 2009; Luo et al. 2011; Gong et al. 2014; Li et al. 2014; Qin et al. 2014; Yutong et al. 2016; $\mathrm{Li}$ et al. 2017). Moreover, the variation of $\mathrm{Hg}_{\mathrm{AF}}$ values was consistent with the progressive increase of $\mathrm{Hg}$ concentrations observed as the aggregate size diminished (Table 2).

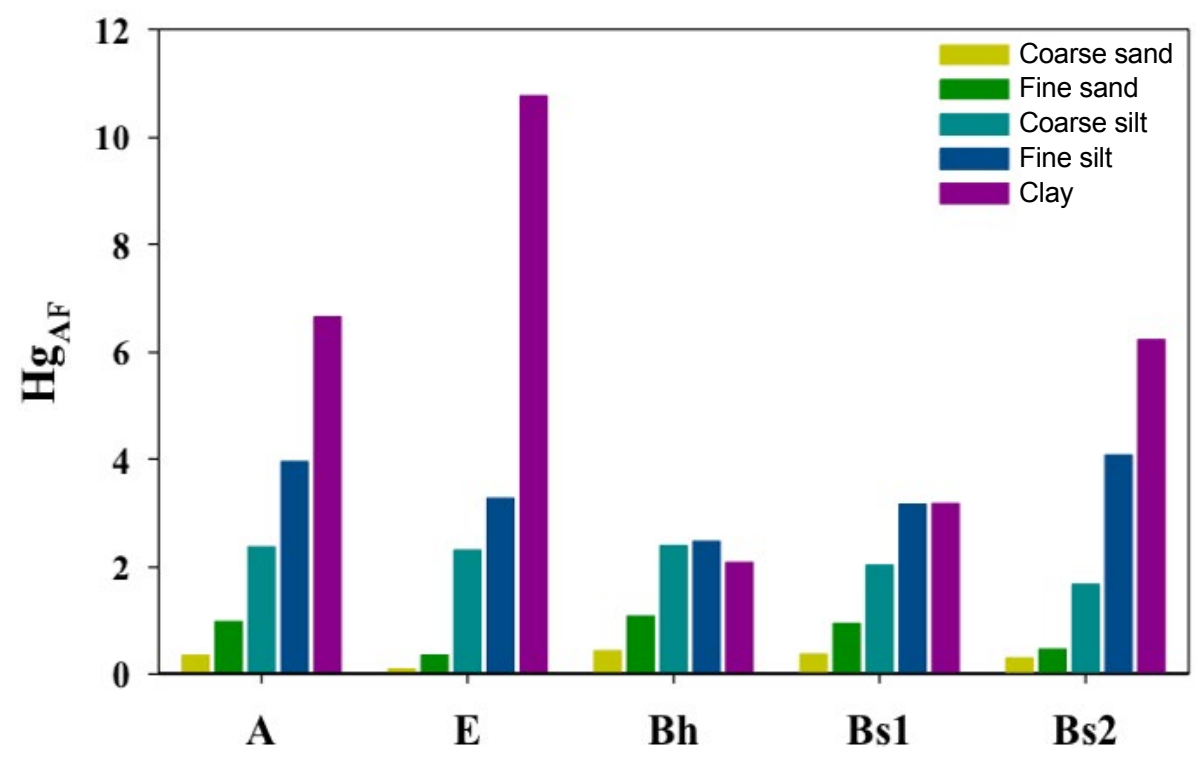

Figure 3. Mercury accumulation factors $\left(\mathrm{Hg}_{\mathrm{AF}}\right)$ in aggregate size fractions by horizons.

Following Yongming et al. (2006), only the coarse silt aggregate size fraction of the $E$ horizon $\left(\mathrm{Hg}_{\mathrm{EF}}=8.7\right.$; Figure 4) can be included in the category "significantly polluted", which corresponds to enrichment factor (EF) values between 5 and 20. This result was somewhat contradictory as the $E$ horizon showed the lower value of $\mathrm{Hg}_{\mathrm{T}}$ among the studied horizons
(Table 2), which was consistent with the likely $\mathrm{Hg}$ mobilization to deeper soil layers due to podzolization. Values of $\mathrm{Hg}_{\mathrm{EF}}$ in the category "moderate pollution" (range 2-5) were shown by most of the aggregate size classes in $A$ and $E$ horizons, whereas $\mathrm{Hg}_{\mathrm{EF}}$ values < 2 ("non polluted" or "slight polluted" categories) were found for finer fractions of illuvial horizons. Moreover, 
illuvial horizons (Bh, Bs1 and Bs2) showed a tendency to a diminution of $\mathrm{Hg}_{\mathrm{EF}}$ values as the smaller was the aggregate size (Figure 4). There are few studies estimating $\mathrm{Hg}_{\mathrm{EF}}$ in aggregate size fractions of soils with very low background values. In a recent study, an $\mathrm{Hg}_{\mathrm{EF}}$ value of 8.2 was obtained for the fraction $<2 \mu \mathrm{m}$ of Chinese soils (Qin et al. 2014). On the other hand, in $\mathrm{Hg}$ contaminated soils, Li et al. (2014) reported $\mathrm{Hg}_{\mathrm{EF}}$ up to 50 in the clay particle size $(<2 \mu \mathrm{m})$ from soils polluted by gold mining.

Lower $\mathrm{Hg}_{\mathrm{EF}}$ in illuvial horizons than in $\mathrm{A}$ and $\mathrm{E}$ horizons were also unexpected as the former had greater total $\mathrm{Hg}$ concentrations (Table 2). This can be justified by the considerable increase of $\mathrm{Al}_{\mathrm{n}}$ values in the finer fractions (silt and clay) observed in Bh, Bs1 and Bs2 horizons (Table 2). Higher $\mathrm{Hg}_{\mathrm{EF}}$ levels in coarser fractions than in finer fractions disagree with the results reported by Acosta et al. (2009) and Yutong et al. (2016), who found the greater EF values for heavy metals in aggregate fractions of silt and clay sizes. Heavy metals enrichment in the finer fractions was attributed to coprecipitation, absorption, adsorption and complexation reactions that favoured metal accumulation in fine particles due to its high surface area and negative charges (Qin et al. 2014). However, discrepancies in $\mathrm{Hg}_{\mathrm{EF}}$ values regarding the size of aggregates between our study and those for Acosta et al. (2009) and Yutong et al. (2016) could be due to the absence of double normalization for $\mathrm{Hg}_{\mathrm{EF}}$ estimation.

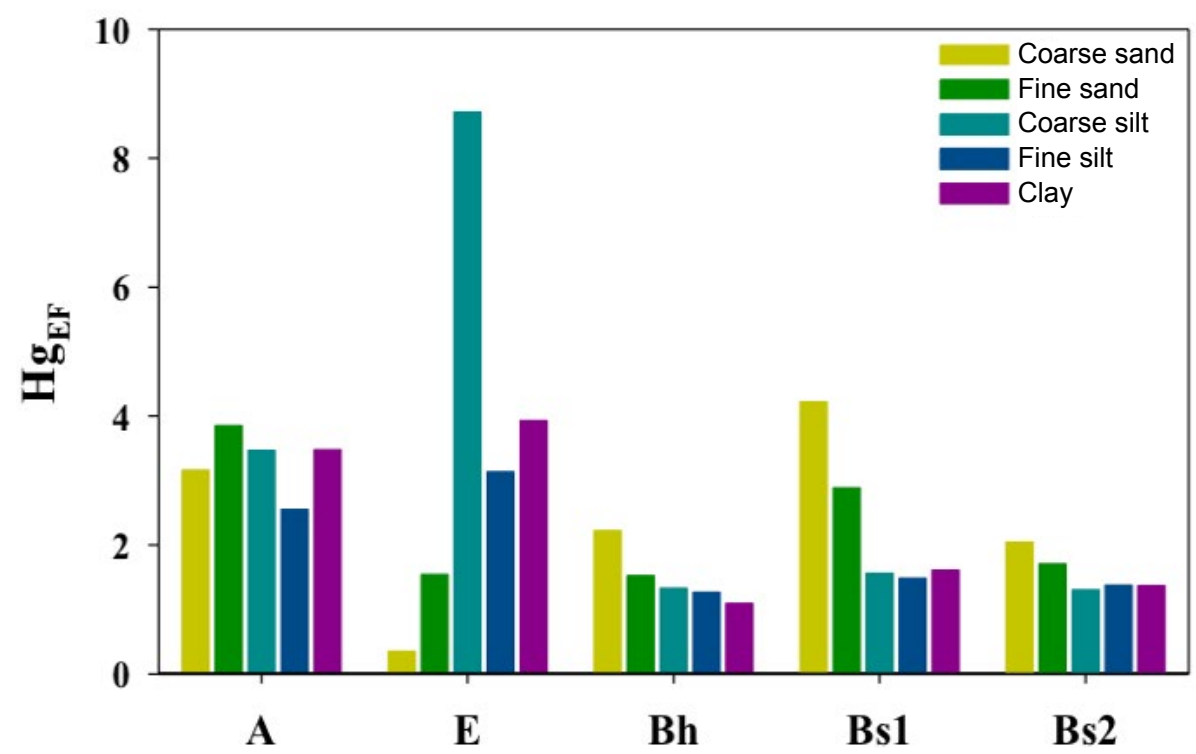

Figure 4. Mercury enrichment factors $\left(\mathrm{Hg}_{\mathrm{EF}}\right)$ in aggregate size fractions by horizons.

The proportions of $\mathrm{Hg}$ loading $\left(\mathrm{GSF}_{\mathrm{Hg}}\right)$ among aggregate size fractions for the soil are presented in Figure 5, revealing notable differences in $\mathrm{GSF}_{\mathrm{Hg}}$ among aggregate size fractions and horizons. A general view of the results indicates that finer fractions (including coarse silt, fine silt and clay aggregates) showed proportionally a higher $\mathrm{Hg}$ loading compared to their mass fractions. Regarding to this, Xiao et al. (2016) considered that the high metal loading that occur in $<53 \mu \mathrm{m}$ aggregates (equivalent to silt plus clay-sized aggregates in the present study), played a key role in heavy metal reservoirs for sandy soils. On the contrary, Gong et al. (2014) found that mass loading in the fraction $<53 \mu \mathrm{m}$ was below $23 \%$ for the assessed heavy metals. Moreover, our results were in agreement with those that attributed high GSF values of heavy metals in finer particles to their greater accumulation of secondary minerals and organic matter (Luo et al. 2011; Yutong et al. 2016; Xiao et al. 2016; Li et al. 2017). This explanation is also applicable to the present study, as finer aggregates were considerably enriched in organic $\mathrm{C}$, metal(Al, $\mathrm{Fe}$ )-humus complexes and $\mathrm{Al}$ and $\mathrm{Fe}$ oxyhydroxides compared to coarse fractions (Table 2). 


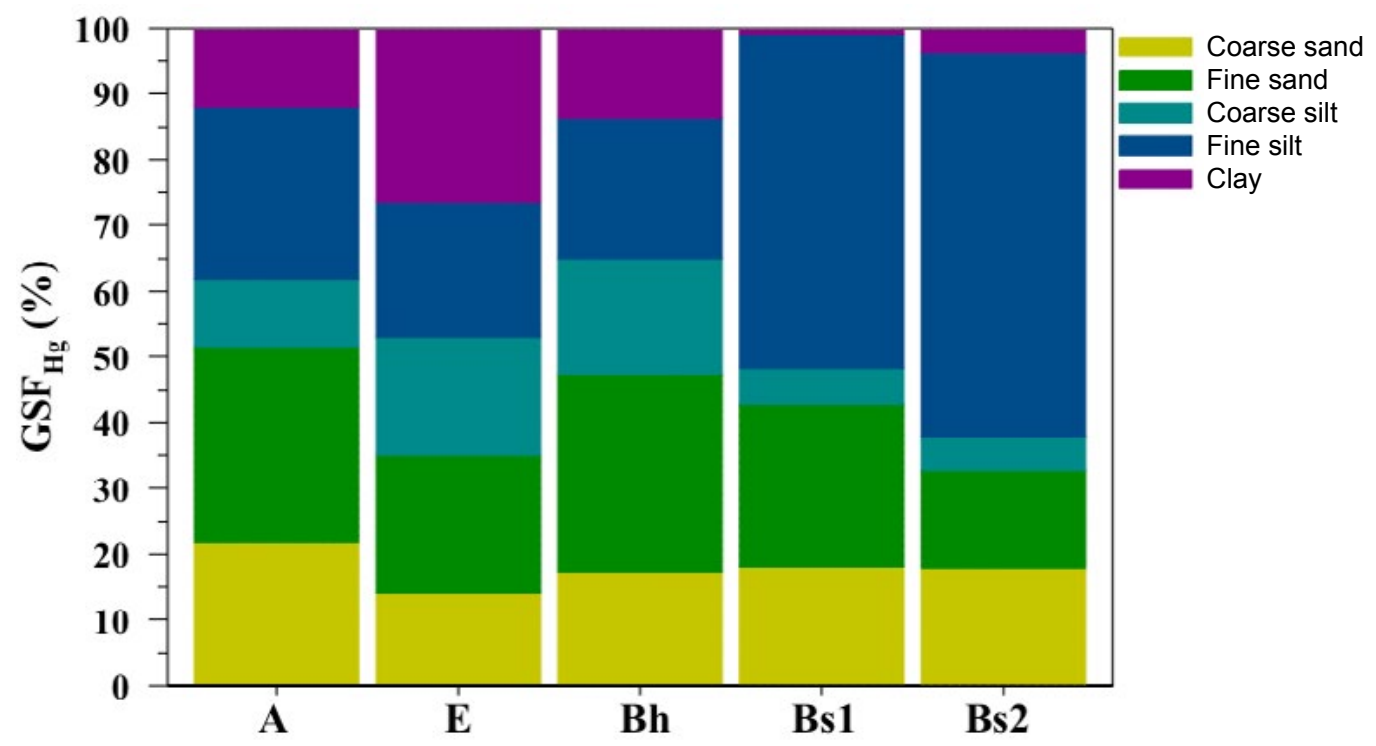

Figure 5. Mercury grain size mass loading $\left(\mathrm{GSF}_{\mathrm{Hg}}\right)$ in aggregate size fractions by horizons.

In the present study, coarse sand aggregates had relatively similar $\mathrm{GSF}_{\mathrm{Hg}}$ values in all horizons (14-22\%), whereas fine silt showed the highest $\mathrm{GSF}_{\mathrm{Hg}}$ in Bs1 and Bs2 horizons where more than $50 \%$ of $\mathrm{Hg}_{\mathrm{T}}$ was accumulated in these fractions in spite of their mass proportions were below $17 \%$. In clay aggregates, $\mathrm{GSF}_{\mathrm{Hg}}$ was especially high in the $\mathrm{A}, \mathrm{E}$ and $\mathrm{Bh}$ horizons, reaching values in the range $12-26 \%$. However, in the spodic horizons, $\mathrm{GSF}_{\mathrm{Hg}}$ of clay aggregates was lower than expected (1-4\%), although still higher than their mass proportions. Finally, $\mathrm{GSF}_{\mathrm{Hg}}$ for coarse silt aggregates ranged from values around $5 \%$ in Bs1 and Bs2 to $18 \%$ in $\mathrm{E}$ and Bh horizons (Figure 5). Our study revealed a remarkable contribution of the silt-sized aggregates to $\mathrm{Hg}$ loading (range $29-63 \%$ depending soil horizon), well above the $25 \%$ attributed to these size fractions in soils from a coal-mine brownfield (Li et al. 2017). In a previous study, Ljung et al. (2006) reported a $\mathrm{GSF}_{\mathrm{Hg}}$ value of approximately $32 \%$ for the fraction $<50 \mu \mathrm{m}$ of Swedish playground soils. The relevance of the silt-sized aggregates in $\mathrm{GSF}_{\mathrm{Hg}}$ and its relationship to the accumulation they showed in terms of metal humus-complexes and $\mathrm{Al}$ and $\mathrm{Fe}$ oxyhydroxides, are consistent with the results obtained by Parry et al. (2011). These authors considered the silt fraction $(2-63 \mu \mathrm{m})$ as the main responsible of bulk soil surface area and reactivity, showing a great relevance for element release via mineral dissolution.
The values of $\mathrm{PERI} \mathrm{Hg}_{\mathrm{Hg}}$ for the different horizons of the AP soil showed an increasing trend with the diminution of the aggregate size (Table 3 ). The lower values of PERI $\mathrm{Hg}_{\mathrm{g}}$ that correspond to the $\mathrm{E}$ horizon ranged from 3 (slight risk) to 363 (extremely high risk). On the contrary, illuvial horizons (Bh, Bs1 and Bs2) showed the highest values ranging from 45 to 903 . Regarding the size of aggregates, as expected, the smallest aggregates (fine silt and clay) are those with the highest $\mathrm{PERI} \mathrm{Hg}_{\mathrm{g}}$ which in most cases fall in the category of extremely high risk ( $\geq 320$ ), although this value was also overcome by coarse silt aggregates from Bh horizon (Table 3 ). In sand size aggregates, values of $\mathrm{PERI} \mathrm{Hg}_{\mathrm{Hg}}$ were mostly classified as medium and high risk, excluding those for $\mathrm{E}$ horizons which fell into the slight risk level. The association of the highest values of $\mathrm{PERI} \mathrm{Hg}_{\mathrm{g}}$ to finer aggregates was consistent with the results obtained in previous studies. Thus, Li et al. (2017) found that aggregate fractions of size $<10 \mu \mathrm{m}$ exhibited very strong ecological risk for $\mathrm{Hg}$, although their values were somewhat lower (range 24-498) than those obtained in the present study. On the contrary, in $\mathrm{Hg}$ contaminated areas PERI levels were considerably higher than our values showing ranges for the $<2 \mu \mathrm{m}$ fraction of 201-12625 (Li et al. 2014) and 299-3007 (Qin et al. 2014). From an environmental perspective, greater 
$\mathrm{PERI}_{\mathrm{Hg}}$ values in the finer particles could mean an increasing risk of pollution due to their easier transport, either in soil solution or by runoff in the case of surface horizons.

Overall, the accumulation and enrichment of $\mathrm{Hg}$ in finer aggregate size fractions needs to be studied in detail in terms of $\mathrm{Hg}$ mobility and environmental risks in podzols and podzolic soils. Firstly, $\mathrm{Hg}_{\mathrm{T}}$ concentrations in finer aggregates (silt plus clay) in illuvial horizons of the AP soil are close, or even higher, to the critical load of $\mathrm{Hg}$ for soils established in $130 \mathrm{ng} \mathrm{g}^{-1}$ (Tipping et al. 2010). Besides, mercury accumulation in fine aggregates could facilitate its migration to deeper soil layers, extending the soil thickness potentially affected by its presence and/or its transference to groundwater. Mercury mobilization towards deeper soil layers, or even to groundwater, could be favoured by the low size of finer aggregates while the prevailing geochemical conditions in podzols also would facilitate metal leaching complexed with dissolved organic matter (Schlüter 1997). This possibility would be supported by the results of Semlali et al. (2001) who observed that not all $\mathrm{Pb}$ mobilized from uppermost soil layers of a podzol was retained in illuvial horizons, as an important proportion migrated to deeper horizons and, ultimately to groundwater. In this sense, leachability tests on aggregate size fractions could lead to obtain information in detail about $\mathrm{Hg}$ mobility in the AP soil, although this was beyond the aims of the present study. In spite of this potential mobility, organic matter and clay minerals accumulated in finer fractions can reduce the bioaccessibility of heavy metals (Cai et al. 2016).

Table 3. Mercury potential ecological risk values $\left(\mathrm{PERI} \mathrm{Hg}_{\mathrm{Hg}}\right.$ ) by aggregate size fraction in the Acibro Podzol

\begin{tabular}{ccccccc} 
Hor & Depth & Coarse sand & Fine sand & Coarse silt & Fine silt & Clay \\
& $c m$ & $(200-2000 \mu m)$ & $(50-200 \mu m)$ & $(20-50 \mu m)$ & $(2-20 \mu m)$ & $(<2 \mu m)$ \\
\hline A & $0-15$ & 25 & 68 & 165 & 277 & 464 \\
E & $15-42$ & 3 & 12 & 78 & 110 & 363 \\
Bh & $42-50$ & 56 & 140 & 305 & 314 & 266 \\
Bs1 & $50-60$ & 67 & 165 & 361 & 560 & 562 \\
Bs2 & $60-80$ & 45 & 68 & 241 & 590 & 903 \\
\hline
\end{tabular}

\section{Conclusions}

The aggregate size influenced notably the partitioning of $\mathrm{Hg}$ in a pristine soil as the Acibro Podzol. Although the sand-size fractions dominated the aggregate distribution, the higher $\mathrm{Hg}_{\mathrm{T}}$ values corresponded to silt and clay-size aggregates which showed significant higher values of $\mathrm{Hg}_{\mathrm{T}}$ compared to bulk soil. This circumstance was attributed to the greater specific surface area and to the enrichment in secondary minerals and organic matter showed by silt and clay size particles. The considerable accumulation of total and Na-pyrophosphate extractable $\mathrm{C}$, metal( $\mathrm{Al}, \mathrm{Fe}$ )-humus complexes and $\mathrm{Al}$ and $\mathrm{Fe}$ oxyhydroxides in the finer fractions supports this.
The mercury accumulation factor $\left(\mathrm{Hg}_{\mathrm{AF}}\right)$ confirmed the accumulation of this metal in the fine fractions. According to grain size mass loading $\left(\mathrm{GSF}_{\mathrm{Hg}}\right)$, silt and clay size fractions showed a greater $\mathrm{Hg}$ load than their mass fractions probably due to the accumulation of organic $\mathrm{C}$ and secondary minerals. Moreover, the contribution of fine silt to $\mathrm{Hg}$ mass loading in illuvial horizons was remarkable. Based on $\mathrm{GSF}_{\mathrm{Hg}}$ values, it is necessary to assess the potential consequences in terms of $\mathrm{Hg}$ mobilization to deeper soil layers or even to groundwater. As it was expected, the highest values of $\mathrm{PERI}_{\mathrm{Hg}}$ were found in finer aggregates which showed very strong ecological risk. The accumulation of $\mathrm{Hg}$ in the fine aggregate fractions could favour $\mathrm{Hg}$ mobilization due to the close relationship between $\mathrm{Hg}$ and organic $\mathrm{C}$ in podzols. Furthermore, physical mobilization of 
$\mathrm{Hg}$ in coarser aggregates through runoff cannot be excluded in surface horizons.

The heterogeneous distribution of $\mathrm{Hg}$ among aggregate size fractions suggests that the selection of a size fraction for $\mathrm{Hg}$ analyses must be carried out with caution, especially if this value is afterwards used for determining critical loads, background values, toxicity thresholds, environmental risk indices, etc. Moreover, $\mathrm{Hg}$ distribution among aggregate size fractions needs to be considered in the assessment of its geochemical mobility in forest soils, especially in podzols and podzolic soils where podzolization already contributes to $\mathrm{Hg}$ transference to subsurface horizons.

\section{Acknowledgements}

This work was supported by the Consellería de Cultura, Educación e Ordenación Universitaria (Xunta de Galicia) with a Reference Competitive Groups grant (ED431C2017/62) to BV1 Research Group. Xunta de Galicia is acknowledged by the pre-doctoral fellowship of A. G. A. (ED481A-2016/220). We also thank to the Seguridade Alimentaria e Desenvolvemente Sostible service of CACTI-University of Vigo for soil chemical characterization.

\section{REFERENCES}

- Acosta JA, Cano AF, Arocena JM, Debela F, MartínezMartínez S. 2009. Distribution of metals in soil particle size fractions and its implication to risk assessment of playgrounds in Murcia city (Spain). Geoderma 149(12):101-9

- Aguilar J, Benayas J, Macías F. 1980. Procesos de edafogénesis. I. Podsolización. Anales de Edafología y Agrobiología 39:1895-1992.

- Bertsch PM, Bloom PR. 1996. Aluminum. In: Sparks DL, editor. Methods of soil analysis. Part 3. Chemical methods. Madison: Soil Science Society of America. 517 p.

- Biester H, Scholz C. 1997. Determination of mercury binding forms in contaminated soils: Mercury pyrolysis versus sequential extractions. Environ Sci Technol. 31(1):233-239.

- Buurman P, Jongmans AG. 2005. Podzolisation and soil organic matter dynamics. Geoderma 125(1-2):71-83.

- Cai M, McBride MB, Li K. 2016. Bioaccessibility of $\mathrm{Ba}, \mathrm{Cu}, \mathrm{Pb}$, and $\mathrm{Zn}$ in urban garden and orchard soils. Environ Pollut. 208:145-152.

- Do Valle CM, Santana GP, Augusti R, Egreja Filho FB, Windmöller CC. 2005. Speciation and quantification of mercury in oxisol, ultisol, and spodosol from Amazon (Manaus, Brazil). Chemosphere 58(6):779-792.

- Driscoll CT, Mason RP, Chan HM, Jacob DJ, Pirrone N. 2013. Mercury as a global pollutant: Sources, pathways, and effects. Environ Sci Technol. 47(10):4967-4983.

- Fernández-Martínez R, Loredo J, Ordóñez A, Rucandio MI. 2005. Distribution and mobility of mercury in soils from an old mining area in Mieres, Asturias (Spain). Sci Total Environ. 346(1-3):200-212.

- Fernández-Martínez R, Loredo J, Ordóñez A, Rucandio I. 2014. Mercury availability by operationally defined fractionation in granulometric distributions of soils and mine wastes from an abandoned cinnabar mine. Environ Sci Process Impacts 16(5):1069-1075.

- Ferro-Vázquez C, Nóvoa-Muñoz JC, Costa-Casais M, Klaminder J, Martínez-Cortizas A. 2014. Metal and organic matter immobilization in temperate podzols: A high resolution study. Geoderma 217-218:225-234.

- Fiorentino JC, Enzweiler J, Angélica RS. 2011. Geochemistry of mercury along a soil profile compared to other elements and to the parental rock: Evidence of external input. Water Air Soil Pollut. 221(1-4):63-75.

- García-Rodeja E, Nóvoa JC, Pontevedra X, MartínezCortizas A, Buurman P. 2004. Aluminium fractionation of European volcanic soils by selective dissolution techniques. Catena 56(1-3):155-83. 
- Gee GW and Bauder JW. 1986. Particle-size analysis. In: Klute A, editor. Methods of soil analysis. Part 1. Physical and mineralogical methods. Madison, WI: SSSA, ASA and SSSA. 383 p.

- Gómez-Armesto A, Ferro-Vázquez C, Cutillas-Barreiro L, Costas-Casais M, Arias-Estévez M, Nóvoa-Muñoz JC, Martínez-Cortizas A. 2015. Distribution and accumulation of total $\mathrm{Hg}$ in high vertical resolution sampled temperate forest podzols from Galicia (NW Spain). In: Abstract Book of the 10th Iberian and 7th Iberoamerican Congress on Environmental Contamination and Toxicology; $2015 \mathrm{Jul}$ 14-17; Vila Real, Portugal. p. 287. ISBN: 978-989-704210-2.

- Gong C, Ma L, Cheng H, Liu Y, Xu D, Li B, Liu F, Ren Y, Liu Z, Zhao C, et al. 2014. Characterization of the particle size fraction associated heavy metals in tropical arable soils from Hainan Island, China. J Geochem Explor. 139:109-114.

- Guedron S, Grangeon S, Lanson B, Grimaldi M. 2009. Mercury speciation in a tropical soil association; consequence of gold mining on $\mathrm{Hg}$ distribution in French Guiana. Geoderma 153(3-4):331-346.

- Gunda T, Scanlon TM. 2013. Topographical influences on the spatial distribution of soil mercury at the catchment scale. Water Air Soil Pollut. 224(4):1511.

- Hakanson L. 1980. An ecological risk index for aquatic pollution control. A sedimentological approach. Water Res. 14(8):975-1001.

- He N, Wu L, Wang Y, Han X. 2009. Changes in carbon and nitrogen in soil particle-size fractions along a grassland restoration chronosequence in Northern China. Geoderma 150(3-4):302-308.

- Inácio MM, Pereira V, Pinto MS. 1998. Mercury contamination in sandy soils surrounding an industrial emission source (Estarreja, Portugal). Geoderma 85(4):325-339.

- IUSS Working Group WRB. 2006. World reference base for soil resources 2006. World Soil Resources Reports No. 103. Rome: FAO.

- Jing YD, He ZL, Yang XE. 2007. Effects of pH, organic acids, and competitive cations on mercury desorption in soils. Chemosphere 69(10):1662-1669.

- Li Q, Ji H, Qin F, Tang L, Guo X, Feng J. 2014. Sources and the distribution of heavy metals in the particle size of soil polluted by gold mining upstream of Miyun reservoir, Beijing: Implications for assessing the potential risks. Environ Monit Assess. 186(10):6605-6626.

- Li H, Ji H, Shi C, Gao Y, Zhang Y, Xu X, Ding H, Tang L, Xing Y. 2017. Distribution of heavy metals and metalloids in bulk and particle size fractions of soils from coal-mine brownfield and implications on human health. Chemosphere 172:505-515.

- Ljung K, Selinus O, Otabbong E, Berglund M. 2006. Metal and arsenic distribution in soil particle sizes relevant to soil ingestion by children. Appl Geochem. 21(9):16131624
- Luo XS, Yu S, Li XD. 2011. Distribution, availability, and sources of trace metals in different particle size fractions of urban soils in Hong Kong: Implications for assessing the risk to human health. Environ Pollut. 159(5):13171326.

- Mason RP, Sheu G. 2002. Role of the ocean in the global mercury cycle. Global Biogeochem Cycles 16(4):40-41.

- Parry SA, Hodson ME, Oelkers EH, Kemp SJ. 2011. Is silt the most influential soil grain size fraction? Appl Geochem. 26(SUPPL.):S119-S122.

- Peech M, Alexander LT, Dean LA, Reed JF. 1947. Methods of soil analysis for soil fertility investigations. Washington, D.C.: U.S. Dep Agr Cir 757, US Gov Print Office.

- Peña-Rodríguez S, Pontevedra-Pombal X, Gayoso EGR, Moretto A, Mansilla R, Cutillas-Barreiro L, AriasEstévez M, Nóvoa-Muñoz JC. 2014. Mercury distribution in a toposequence of sub-antarctic forest soils of Tierra del Fuego (Argentina) as consequence of the prevailing soil processes. Geoderma 232-234:130-140.

- Qin F, Ji H, Li Q, Guo X, Tang L, Feng J. 2014. Evaluation of trace elements and identification of pollution sources in particle size fractions of soil from iron ore areas along the Chao River. J Geochem Explor. 138:33-49.

- Richardson JB, Friedland AJ, Engerbretson TR, Kaste JM, Jackson BP. 2013. Spatial and vertical distribution of mercury in upland forest soils across the Northeastern United States. Environ Pollut. 182:127-134.

- Roulet M, Lucotte M. 1995. Geochemistry of mercury in pristine and flooded ferralitic soils of a tropical rain forest in French Guiana, South America. Water Air Soil Pollut. 80(1-4):1079-1088.

- Roulet M, Lucotte M, Saint-Aubin A, Tran S, Rhéault I, Farella N, De Jesus Da Silva E, Dezencourt J, Sousa Passos CJ, Santos Soares G, et al. 1998. The geochemistry of mercury in central Amazonian soils developed on the Alter-do-Chao formation of the lower Tapajos River Valley, Para State, Brazil. Sci Total Environ. 223(1):1-24.

- Sauer D, Sponagel H, Sommer M, Giani L, Jahn R, Stahr K. 2007. Podzol: Soil of the year 2007. A review on its genesis, occurrence, and functions. J Plant Nutr Soil Sci. 170(5):581-597.

- Schlüter K. 1997. Sorption of inorganic mercury and monomethyl mercury in an iron-humus podzol soil of southern Norway studied by batch experiments. Environ Geol. 30(3-4):266-279.

- Schuster E. 1991. The behaviour of mercury in the soil with special emphasis on complexation and adsorption processes - A review of the literature. Water Air Soil Pollut. 56(1):667-680.

- Semlali RM, Van Oort F, Denaix L, Loubet M. 2001. Estimating distributions of endogenous and exogenous $\mathrm{Pb}$ in soils by using $\mathrm{Pb}$ isotopic ratios. Environ Sci Technol. 35(21):4180-4188. 
- Skyllberg U, Bloom PR, Qian J, Lin CM, Bleam WF. 2006. Complexation of mercury(II) in soil organic matter: EXAFS evidence for linear two-coordination with reduced sulfur groups. Environ Sci Technol. 40(13):4174-4180.

- Smith-Downey NV, Sunderland EM, Jacob DJ. 2010. Anthropogenic impacts on global storage and emissions of mercury from terrestrial soils: Insights from a new global model. J Geophys Res G Biogeosci. 115(3): G03008.

- Stemmer M, Gerzabek MH, Kandeler E. 1998. Organic matter and enzyme activity in particle-size fractions of soils obtained after low-energy sonication. Soil Biol Biochem. 30(1):9-17.

- Sutherland RA. 2003. Lead in grain size fractions of road-deposited sediment. Environ Pollut. 121(2):229-237.

- Tipping E, Lofts S, Hooper H, Frey B, Spurgeon D, Svendsen C. 2010. Critical limits for $\mathrm{Hg}(\mathrm{II})$ in soils, derived from chronic toxicity data. Environ Pollut. 158(7):24652471.

- Xiao R, Zhang M, Yao X, Ma Z, Yu F, Bai J. 2016. Heavy metal distribution in different soil aggregate size classes from restored brackish marsh, oil exploitation zone, and tidal mud flat of the Yellow River delta. J Soils Sed. 16(3):821-830.

- Xin M, Gustin MS. 2007. Gaseous elemental mercury exchange with low mercury containing soils: Investigation of controlling factors. Appl Geochem. 22(7):1451-1466.

- Yongming H, Peixuan D, Junji C, Posmentier ES. 2006. Multivariate analysis of heavy metal contamination in urban dusts of Xi'an, Central China. Sci Total Environ. 355(1-3):176-186.

- Yutong Z, Qing X, Shenggao L. 2016. Distribution, bioavailability, and leachability of heavy metals in soil particle size fractions of urban soils (Northeastern China). Environ Sci Pollut Res. 23(14):14600-14607. 